\title{
The Role of Vitamin D on Fluoxetine Induced Testicular Toxicity in Adult Male Rats
}

\author{
Yasmeen Mohammed Ismail El Sayed ${ }^{1}$, Nagah EI Sayed Mohammed Ali ${ }^{2^{*}}$, Amal Mahmoud \\ EISafy Elshazly ${ }^{3}$, Rabab Fawzy Salm ${ }^{4}$, Bodour Qassim Badreldeen Baioumy ${ }^{3}$ and Heba Abd \\ El Hafeez El Noury ${ }^{1}$.
}

\begin{tabular}{|c|c|}
\hline & ABSTRACT \\
\hline $\begin{array}{l}\text { KEYWORDS } \\
\text { Fluoxetine, } \\
\text { Cytokines, } \\
\text { Vitamin D, } \\
\text { Antioxidant effects, } \\
\text { Testis. }\end{array}$ & 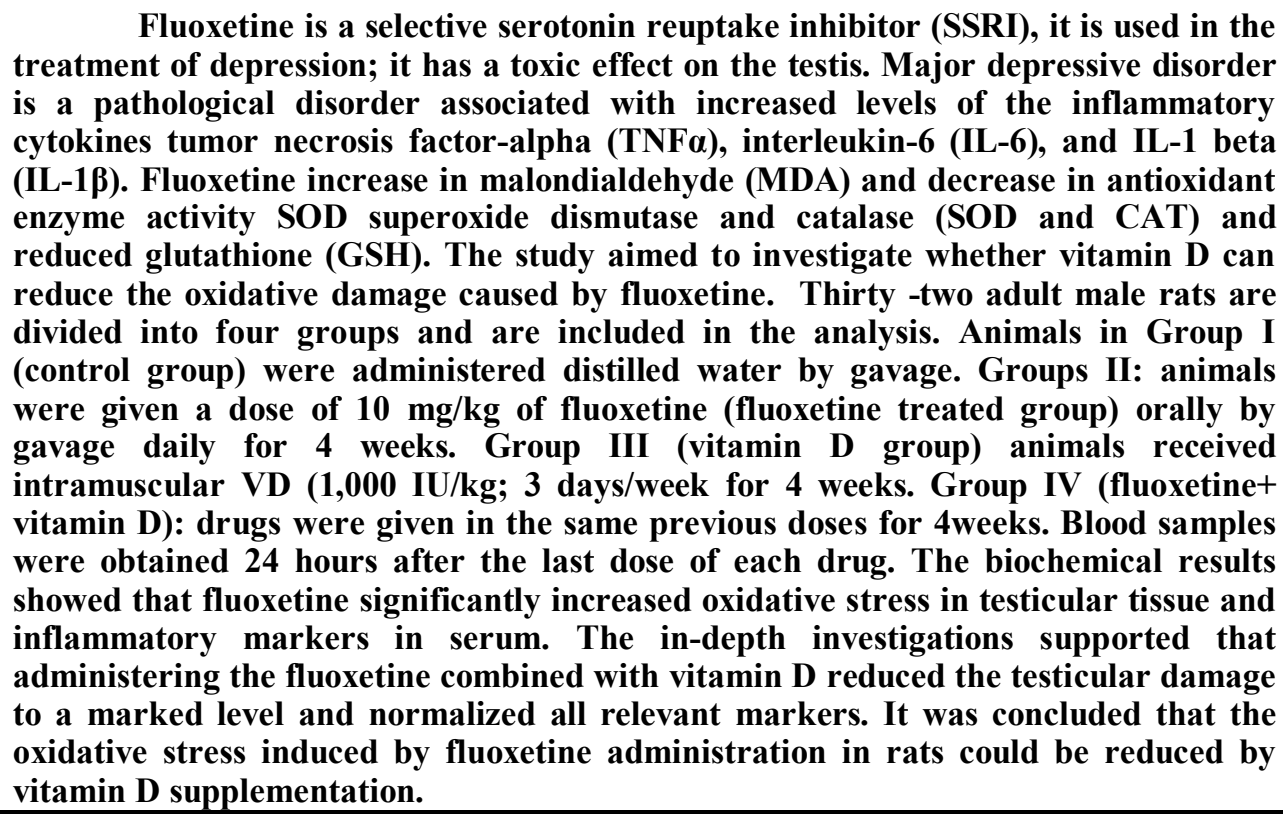 \\
\hline
\end{tabular}

\section{Introduction}

Depression is a common and recurring mood disorder that causes adjustment problems for both economic and social

\footnotetext{
(1) Clinical Pharmacology Department, Faculty of Medicine, Benha University, Benha 13518, QG, Egypt

(2) Forensic Medicine and Clinical Toxicology Department, Faculty of Medicine, Benha University, Benha 13518, QG, Egypt.

(3) Anatomy Department, Faculty of Medicine, Benha University, Benha 13518, QG, Egypt.

(4) Medical Biochemistry and Molecular Biology Department, Faculty of Medicine, Benha University, Benha 13518, QG, Egypt.

*Corresponding author: Nagah Elsayed Mohammed Ali. Email:nageh.ali@fmed.bu.edu.eg.
}

purposes. Depression is much more common at the onset of adolescence (Wille et al., 2008).

Fluoxetine, one type of selective serotonin reuptake inhibitor (SSRI), is used in the treatment of neuropsychiatric disorders such as depression, bulimia, and obsessivecompulsive disorders (Jalili et al., 2014).

Major depressive disorder (MDD) is a debilitating disorder associated with increased levels of the inflammatory cytokines tumor necrosis factor-alpha (TNF $\alpha)$, interleukin-6 (IL-6), and IL-1 beta (IL-1 $\beta$ ). Interleukin-10 (IL-10) is a key regulator of depression symptoms and modulates depressive-like 
behavior (Howren et al., 2009; Dowlati et al., 2010).

Fluoxetine increase in malondialdehyde (MDA) and decrease in antioxidant enzyme activity SOD superoxide dismutase and catalase (SOD and CAT) and reduced glutathione (GSH) (Hussein et al., 2015).

The effect of fluoxetine was examined by some researchers. Administration of fluoxetine caused the reduction of testicular and ovarian weights in mice (Sakr et al., 2013).

Vitamin D (VD) is produced in the skin as a prohormone following sunlight exposure and is produced in the kidney after activation by $1 \alpha$ hydroxylase cytochrome P450 family 27 subfamilies B member 1 (Cyp27b1) in renal proximal tubular cells (Refaat et al.,2017). VD can be bound by the protein (vitamin D binding protein) and broken down into smaller molecules by the catabolic enzyme cytochrome P450 family 24 subfamilies A member 1 ( Cyp24a1) (Refaat et al., 2015).

The vitamin $\mathrm{D}$ receptor is located in the cytoplasm binds to retinoid $\mathrm{x}$ receptors to form a complex. It binds to three of the nine vitamin $\mathrm{D}$ receptor (VDR) elements and controls their expression (Carlberg and Campbell, 2013).

There is a wide range of defense mechanisms of VD. They promote healing of wounds, reduce the symptoms of rheumatism and arthritis, and also relieve inflammation in other parts of the body (Carlberg and Campbell, 2013; Chow et al., 2013; Abdelghany et al., 2016).

Vitamin D and fluoxetine, induced testicular damage, are poorly understood, and the available data is controversial. This study was designed to measure the effects of VD on oxidative stress markers and some proinflammatory cytokines in the tests of rats given fluoxetine during the study (Lopez et al., 2015).

\section{Material and Methods}

Thirty - two adult male Wistar rats (200 and $250 \mathrm{~g}, 8-10$ weeks old) were bred in four cages. The rats were housed in a room at $24^{\circ} \mathrm{C}$ under a 12 -h light $/ 12$-h dark cycle, with access to food and water. All experiments must be performed under general anesthesia.

Study Design and treatment protocols: were approved by the Committee on the Research and the animals in Biomedical Research at Benha Faculty of Medicine was performed following the EU regulation on animal experimentation.

\section{Chemicals:}

Fluoxetine was donated by the IE Ulagay-Menarini Group (Cairo, Egypt), malondialdehyde (MDA), and glutathione levels (GSH) were determined using ELISA kits from Cusabio Biotech Co. Ltd. (Hubei, Egypt). Vitamin D3 ampoules $(100,0000$ $\mathrm{IU} / \mathrm{mL}$ ) were from Memphis Co. A type of school supplies was obtained from Pharm. Co. and several chemicals. Independency (Cairo, in Egypt, 1487).

\section{Experimental groups}

Rats were divided equally into four groups; 8 rats for each group. Group I (control group): the animals received distilled water by oral gavage daily for 4 weeks. Group II (fluoxetine-treated group): animals received $10 \mathrm{mg} / \mathrm{kg}$ of fluoxetine (Aggarwal et al., 2012) by oral gavage daily for 4 weeks. Group III (vitamin D treated group): they received intramuscular VD $(1,000 \mathrm{IU} / \mathrm{kg} ; 3$ days/week for 4 weeks (Mohammad, et al .2018). Group IV (fluoxetine + vitamin D 
treated group): drugs were given in the same previous doses for 4 weeks. All drugs were dissolved in distilled water.

\section{Sampling}

After 4 weeks of administration, rats were anesthetized by ether. Next, blood samples were manually collected from the heart of the rats, and their blood chemistry values were analyzed by a veterinary lab. Testicular and epididymis tissues were removed during dissection. The left testis and epididymis were cleaned of blood in a phosphate buffer solution (PBS) (NaCl: $8 \mathrm{~g}$

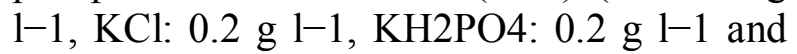
$\mathrm{Na}_{2} \mathrm{HPO}_{4}$ : $1.14 \mathrm{~g} \mathrm{1-1}$ at $\mathrm{pH}$ 7.4) and weighed. The left epididymis was used to document the levels of GSH and MDA in the testicular tissue. The right testis was cleaned of the blood and other biological tissues and fixed for microscopic examination (Johnsen, 1970).

The process was carried out as follows: 1) The remaining left testis pieces were cut into $1-\mathrm{cm}$ sections, and after homogenization in RIPA buffer, 2) The pieces were centrifuged at $3000 \mathrm{rpm}$ for $10 \mathrm{~min}$ at $4{ }^{\circ} \mathrm{C}$, and 3 ) the protein extraction process was carried out with $3 \square \mathrm{ml}$ of RIPA buffer, with protease inhibitors. After centrifugation, small aliquots of the resultant supernatant from each sample were placed in small test tubes and one problem with the experiment was that the concentration of proteins could be measured on a Qubit Fluorometer. Every testicular specimen was then diluted with aqueous saline $(500 \mu \mathrm{g} / \mathrm{mL})$ to prevent deterioration. Next, they were stored at $-20^{\circ} \mathrm{C}$.

\section{Histopathological studies:}

It has been done on all animals of each group and the results were examined at the Pathology Department in Benha Faculty of Medicine. Testis (seminiferous tubules within it) immediately soaked in bruin's solution. Fix for 6- 8 hours and then transfer to $70 \%$ alcohol to "wash out" before submitting to histological examination for automated dehydration, paraffin embedding, then sectioned and stained with hematoxylin and eosin (Kiernan, 2015).

\section{Electron microscopic evaluation:}

The sections from tests were cut using an ultra-microtome; one micron thick [semithin section], with glass knives, then stained with toluidine blue. At Tanta University Electron-microscope Unit, the stained sections were examined at 80 kilovolts and investigated by a transmission electron microscope then photographs were taken, produced, printed, and examined.

Determination of GSH and MDA levels in testes: The GSH and MDA levels in the testis were determined using commercially available kits and according to the instructions of the manufacturer.

\section{Enzyme-linked Immunosorbent Assay}

(ELISA): The serum of the rats was tested against specific ELISA kits (R\&D Systems, MN, USA). All samples were processed in duplicate in an automated immunoassay using the manufacturer's specifications. The lowest ranges of TNF- $\alpha$, IL- 4 , and IL-10 noted at the manufacturers' tested concentrations were $3.1 \square \mathrm{pg} / \mathrm{mL}, \quad \leq 3 \square \mathrm{pg} / \mathrm{mL}$, and $3 \square \mathrm{pg} / \mathrm{mL}$, respectively. The levels of testicular tissue antioxidants, glutathione, superoxide dismutase, catalase, glutathione peroxidase, and malondialdehyde, were also measured by ELISA (Cayman Chemical Co., MI, Egypt).

Gene expression analysis: For realtime-PCR (RT-PCR), total RNA from testicular tissues was extracted using TRIzol reagent (Invitrogen) and quantified by spectrophotometry. cDNA was synthesized using a RevertAid First Strand cDNA Synthesis kit (Thermo Scientific, Rockford, 
IL, USA) following the manufacturer's guidelines. The primers were designed as follows: Bax (F: 5'AAGAAGCTGAGCAGT GTCT-3'; R: 5'CAAAGATGGTCACTGTCT GC-3'), Bcl-2 (F: 5'GTATGATAACCGGGA GATCG-3'; R: 5'AGCCAGGAGAAATCAA ACAG-3') (Rogerio et al., 2006) and glyceraldehyde -3-phosphate dehydrogenase (GAPDH) (F: 5'CGGAGTCAACGGATTT GGTCGTAT-3'; R: 5'AGCCTTCTCCATGG TGGTGAAGAC-3') (Wong et al., 1994). The relative gene expression levels were measured in the step one Real-Time PCR system (Applied Biosystems, USA) using 2x SYBR ${ }^{\circledR}$ Green PCR master mix (Applied Biosystems, U.S.A.). The total $25-\mu$ reaction volume contained $12.5 \mu \mathrm{L}$ of $2 \mathrm{x}$ SYBR $\AA$ Green PCR master mix, $2 \mu \mathrm{L}$ of $\mathrm{cDNA}, 1 \mu \mathrm{L}$ of the forward primer, $1 \mu \mathrm{L}$ of the reverse primer, and $3.5 \mu \mathrm{L}$ Nuclease-free H2O. The PCR conditions were performed according to the following program: $95^{\circ} \mathrm{C}$ for $10 \mathrm{~min}, 40$ cycles of $95^{\circ} \mathrm{C}$ for $15 \mathrm{Sec}$, anneal/extend temperature for $60 \mathrm{Sec}$.

Melting curve analysis using Step One software (Applied Biosystems, USA) was performed to assess the specificity of the amplification products. Relative expression of the target genes in each sample was finally detected after normalization to GAPDH expression and calculated as $2^{\wedge}-\Delta \Delta C t$ (Schmittgen and Livak, 2008) using Step One Software v2.3 (Applied Biosystems, U.S.A.).

\section{Result}

\section{Testicular lipid peroxidation and testicular antioxidant markers:}

As regards, the level of malondialdehyde (MDA), catalase (CAT), and superoxide dismutase (SOD), in group III, Vit $\mathrm{D}$ treatment had no significant effect on the levels of these enzymes in the testicular tissues. However, in Vit D and fluoxetine group, there is a reduction in the levels of the testicular antioxidant glutathione (GSH) compared to the control group ( $23.15 \mathrm{mg} / \mathrm{g}$ and $25.18 \mathrm{mg} / \mathrm{g}$ respectively) also, there is a reduction in the levels of the antioxidant glutathione peroxidase (GPx) concerning the control group $(2.44 \mu \mathrm{g} / \mathrm{mg}$ and $2.67 \mu \mathrm{g} / \mathrm{mg}$ respectively).

Administration of fluoxetine in the fluoxetine-treated group, compared with the control group, significantly increased the serum level of malondialdehyde in the testis $(p=0.00005)$ from $(25.2 \mathrm{nmol} / \mathrm{g})$ in the control group to $(33.5 \mathrm{nmol} / \mathrm{g})$ in the fluoxetine-treated group. The levels of MDA in the testis $(p=0.03)$, obtained from the Vit D treated group $(24.16 \mathrm{mg})$ significantly decreased compared with the fluoxetine treated group (39.7 nmol/g) (Table 1).

Compared to the control rats, levels of GSH, GPx and CAT were lower in the fluoxetine treated rats by $22.3 \%(p=0.04)$, $40 \% \quad(p=0.01)$ and $31.2 \% \quad(p=0.03)$ respectively. No statistically significant difference was found between the levels of SOD between the control group and Vit D group. The simultaneous administration of VD3 and fluoxetine prevented the observed decreases of the testicular antioxidants (Table 1). 
Table (1): Effect of fluoxetine and vitamin D administration on testicular lipid peroxidation and testicular antioxidant markers.

\begin{tabular}{|c|c|c|c|c|}
\hline & $\begin{array}{c}\text { Control group } \\
(\mathbf{n = 8}) \\
{[\text { mean } \pm \mathbf{S D}]}\end{array}$ & $\begin{array}{c}\text { Fluoxetine group } \\
(\mathbf{n = 8}) \\
{[\text { mean } \pm \mathbf{S D}]}\end{array}$ & $\begin{array}{c}\text { Vitamin D group } \\
\mathbf{( n = 8 )} \\
{[\text { mean } \pm \mathbf{S D}]}\end{array}$ & $\begin{array}{c}\text { Fluoxetine +Vitamin D group } \\
(\mathbf{n = 8}) \\
{[\mathbf{m e a n} \pm \mathbf{S D}]}\end{array}$ \\
\hline $\mathrm{MDA}(\mathrm{nmol} / \mathrm{g})$ & $25.2 \pm 3.8$ & $39.7 \pm 5.6$ & $24.16 \pm 4$ & $33.5 \pm 3.2^{\mathrm{b}}$ \\
\hline $\mathrm{GSH}(\mathrm{mg} / \mathrm{g})$ & $25.18 \pm 3$ & $18.01 \pm 3.6$ & $25.16 \pm 3.2$ & $23.15 \pm 3.5$ \\
\hline $\mathrm{GPx}(\mu \mathrm{g} / \mathrm{mg})$ & $2.67 \pm 0.8$ & $1.48 \pm 0.30^{\mathrm{a}}$ & $2.5 \pm 0.5$ & $2.44 \pm 0.9$ \\
\hline $\mathrm{CAT}(\mathrm{U} / \mathrm{mg})$ & $94.33 \pm 16.7$ & $64.61 \pm 14.6^{\mathrm{a}}$ & $94.34 \pm 15.9$ & $92.2 \pm 7.8^{\mathrm{d}}$ \\
\hline $\mathrm{SOD}(\mathrm{U} / \mathrm{mg})$ & $12.4 \pm 1.26$ & $10.65 \pm 1.94$ & $12.1 \pm 2.29$ & $11.32 \pm 2.6$ \\
\hline
\end{tabular}

$\mathrm{MDA}=$ malondialdehyde $\mathrm{GSH}=$ glutathione $\mathrm{GPx}=$ glutathione peroxidase $\mathrm{CAT}=$ catalase $\mathrm{SOD}=$ superoxide dismutase, $\mathrm{n}=$ number, $\mathrm{SD}=$ standard deviation, a-p $<0.05$ relative to the group I,(significant) $\mathrm{b}-\mathrm{p}<0.01$ relative to the group $\mathrm{I}$, (significant) $c-p<0.05$ relative to the group II, ( significant) $d-p<0.01$ significant) relative to the group II).

\section{Serum concentrations of targeted cytokines}

Fluoxetine caused significant increases in serum levels of IL-4 (15.64 $\mathrm{U} / \mu \mathrm{g})$ and TNF- $\alpha \quad(36.31(\mu \mathrm{g} / \mathrm{mg}))$ with a significant reduction in serum IL-10 level $(\mathrm{p}<0.01)$. Within the vitamin D supplemented group, TNF- $\alpha$ and IL-10 levels were restored to levels observed in the control group, and the levels of both cytokines were significantly different among the three test groups. Serum IL-4 concentrations were lower in the fluoxetine + vitamin D group compared with the fluoxetine group which remained significantly higher compared with the control group (Table 2).

Table (2): Effect of fluoxetine and vitamin D administration on serum concentrations of targeted cytokines.

\begin{tabular}{|c|c|c|c|c|}
\hline & $\begin{array}{l}\text { Control group } \\
\qquad \begin{array}{l}(\mathbf{n}=8) \\
{[\text { mean } \pm \text { SD }]}\end{array}\end{array}$ & $\begin{array}{l}\text { Fluoxetine group } \\
\qquad \begin{array}{c}(\mathrm{n}=8) \\
{[\text { mean } \pm \text { SD] }}\end{array} \\
\end{array}$ & $\begin{array}{c}\text { Vitamin D group } \\
\qquad(\mathbf{n}=\mathbf{8}) \\
{[\text { mean } \pm \text { SD] }}\end{array}$ & $\begin{array}{c}\text { Fluoxetine +Vitamin D group } \\
\qquad \begin{array}{c}(\mathrm{n}=8) \\
{[\text { mean } \pm \mathrm{SD}]}\end{array} \\
\end{array}$ \\
\hline TNF- $\alpha$ & $25.02 \pm 3.72$ & $36.31 \pm 7.13^{\mathrm{b}}$ & $26.6 \pm 4.82^{\mathrm{c}}$ & $28.01 \pm 4.6$ \\
\hline IL-4 & $7.81 \pm 1.5$ & $15.64 \pm 2.3^{\mathrm{b}}$ & $8.2 \pm 2.05^{\mathrm{b}, \mathrm{c}}$ & $10.11 \pm 1.4$ \\
\hline IL-10 & $12.65 \pm 2.1$ & $7.02 \pm 1.75^{\mathrm{b}}$ & $11.31 \pm 1.87^{\mathrm{d}}$ & $10.57 \pm 1.7$ \\
\hline
\end{tabular}

TNF- $\alpha=$ tumor necrotic factor-alpha IL-4=interleukin-4 IL-10= interleukin-10. $n=$ number, SD= standard deviation.

\section{Gene expression of proapoptotic (Bax) and anti-apoptotic (Bcl-2)}

There were no significant differences in the relative expression levels of Bax and Bcl2 in the fluoxetine + Vit $D_{3}$ treated group, as compared with the control group ( $\mathrm{p}>0.05)$. Coadministration of Vit D3 with the fluoxetine resulted in a significant decrease in the relative expression levels of Bax, as compared with the fluoxetine treated group $(\mathrm{p}=0.021)$. In contrast, fluoxetine + Vit D3 treated group showed a significant increase in the expression levels of Bcl-2 compared to the fluoxetine treated group $(\mathrm{p}=0.03)$. 
Fluoxetine treated group showed a significant increase in the relative expression levels of $\operatorname{Bax}(\mathrm{p}=0.002)$ that coincided with a significant decrease in the relative expression levels of Bcl-2, as compared with the control group $(\mathrm{p}=0.02)$.
The Vit $D_{3}$ treated group showed significant down-regulation of Bax in the testis compared to the control group $(\mathrm{p}=0.01)$. However, administration of Vit $\mathrm{D}_{3}$ to normal rats didn't alter the expression levels of Bcl-2 compared to the control group $(p>0.05)$ (Table 3).

Table (3): Relative expression levels of Bax and Bcl-2 in the different study groups.

\begin{tabular}{|l|c|c|c|c|}
\hline & $\begin{array}{c}\text { Control group } \\
(\mathbf{n}=\mathbf{8}) \\
{[\text { mean } \pm \mathbf{S D}]}\end{array}$ & $\begin{array}{c}\text { Fluoxetine group } \\
\mathbf{( n = 8 )} \\
{[\text { mean } \pm \mathbf{S D}]}\end{array}$ & $\begin{array}{c}\text { Vitamin D group } \\
\mathbf{( n = 8 )} \\
{[\text { mean } \pm \mathbf{S D}]}\end{array}$ & $\begin{array}{c}\text { Fluoxetine+ Vitamin D group } \\
(\mathbf{n}=\mathbf{8}) \\
{[\text { mean } \pm \mathbf{S D}]}\end{array}$ \\
\hline $\mathrm{Bax}$ & $1.02 \pm 0.04$ & $2.16 \pm 0.72^{\mathrm{b}}$ & $0.77 \pm 0.19^{\mathrm{a}}$ & $1.49 \pm 0.45^{\mathrm{c}}$ \\
\hline $\mathrm{Bcl}-2$ & $1.01 \pm 0.04$ & $0.74 \pm 0.22^{\mathrm{a}}$ & $1.26 \pm 0.36$ & $0.99 \pm 0.08^{\mathrm{c}}$ \\
\hline
\end{tabular}

$\mathrm{n}=$ number, $\mathrm{SD}=$ standard deviation

The histopathological results showed that Vit D supplementation has an ameliorative effect against fluoxetineinduced testicular damage.

As shown in figures (1-5), there is a significant difference between groups regarding electron microscopic picture where $50 \%$ of the fluoxetine treated group had abnormal Sertoli cells with an irregular nucleus, vacuolation, and 50\% had abnormal tubules but $100 \%$ of cells are normal in control and vit D group while $80 \%$ of vit D and fluoxetine group are normal and $20 \%$ are abnormal.

There are well-arranged seminefrous tubules with normal architecture and normal interstitial tissues and cells from control and vit $\mathrm{D}$ group rats (Figures $1 \& 3$ ). Meanwhile, there is dilatation of seminifrous tubules and vacuolation, in fluoxetine treated rat (Figure 2).

Rat's testis prepared from fluoxetine treated rat showed abnormal sertoli cells and basement membrane (Figure 4).

Slight improvement in cells of seminiferous tubules could be seen in the group treated with fluoxetine and vit D (Figure 5).

There is a significant difference between groups regarding light microscopic picture. One hundred percent of control and vit D groups had normal tubules, while in vit $\mathrm{D}$ and fluoxetine treated groups, $80 \%$ had normal tubules and in treated fluoxetine group 50\% had dilatation in seminiferous tubules and vacuolation, while 50\% showed testicular atrophy (Figures 6- 9). 


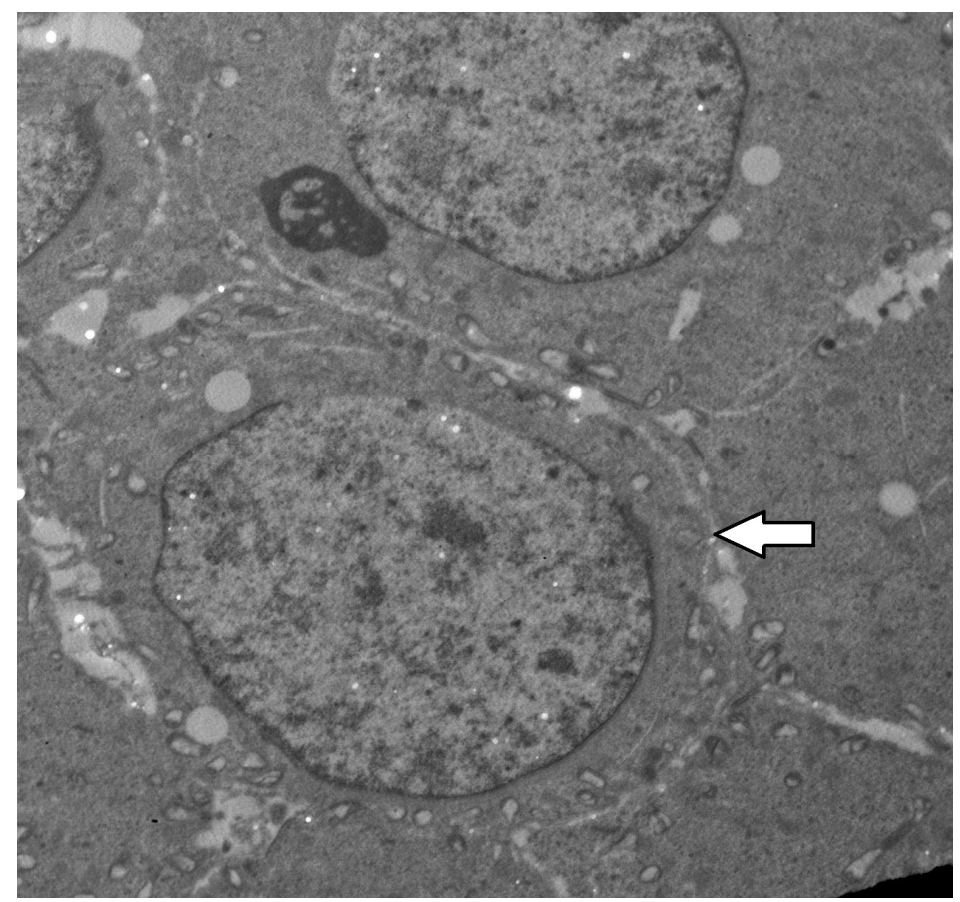

Fig. (1): Electron micrograph of rat's testis from control group showing normal cells within the seminiferous tubules (arrow) (TEM x2000)

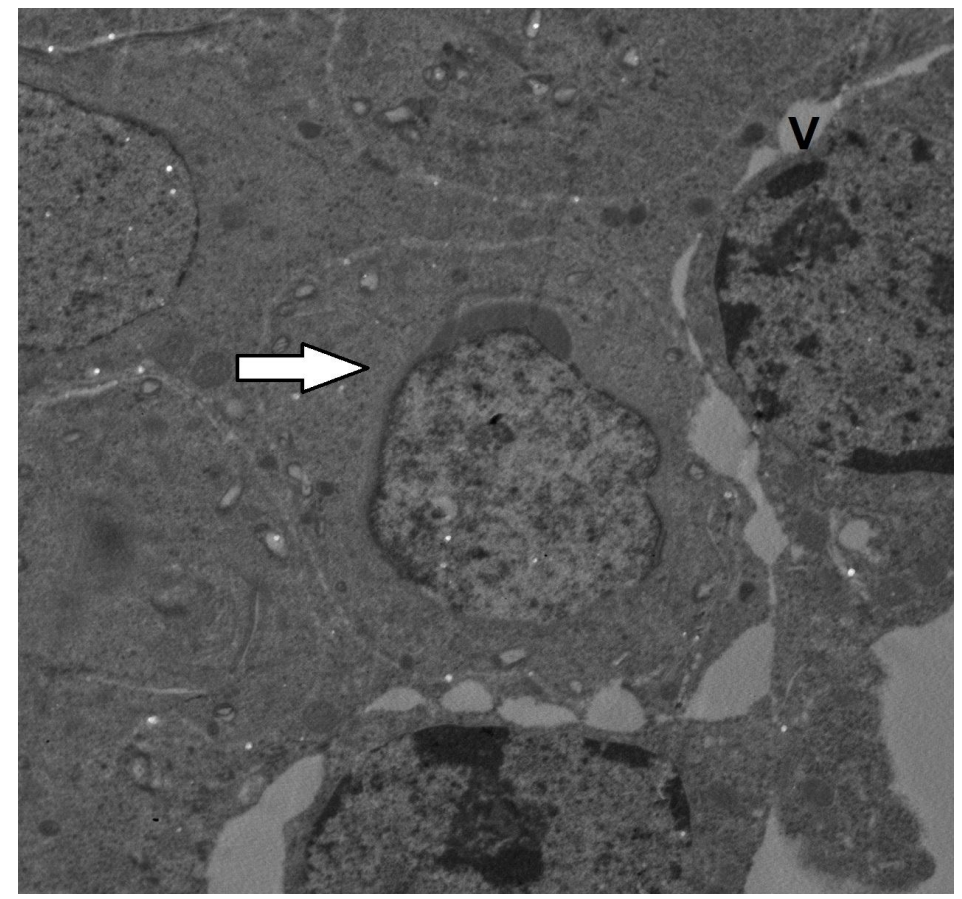

Fig. (2): Electron micrograph of rat's testis prepared from fluoxetine- treated rat showing abnormal degenerated cells and vacuolation (v) within seminiferous tubules (arrow) (TEM x2000). 


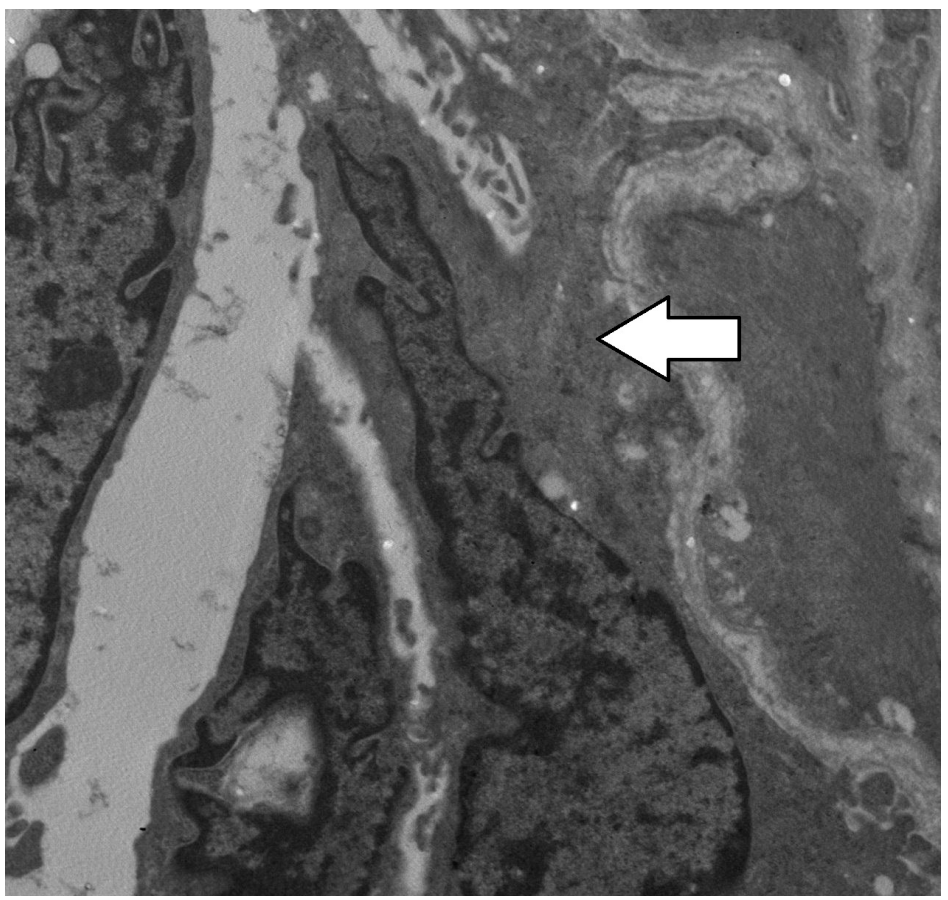

Fig. (3): Electron micrograph of rat's testis prepared from normal rat received vitamin $\mathrm{D}$ showing part of seminiferous tubule with normal architecture and normal interstitial tissues and cells (arrow) (TEMx2000).

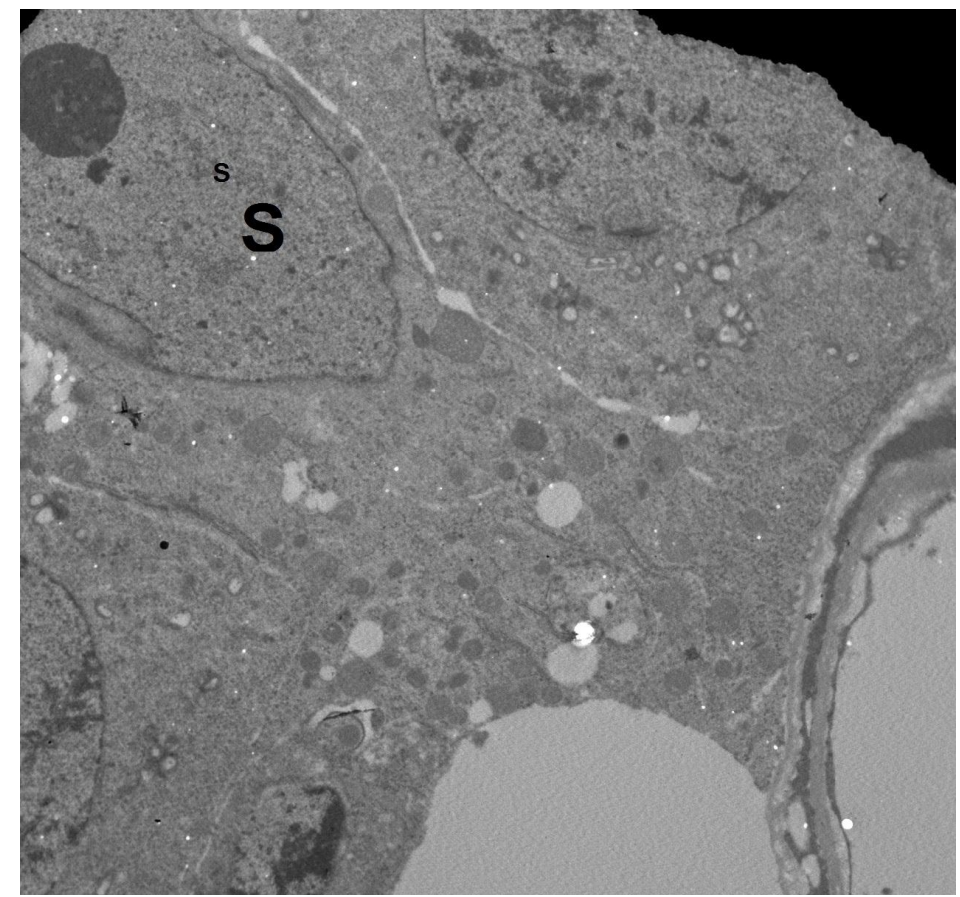

Fig. (4): Electron micrograph of rat's testis prepared from fluoxetine treated rat showing abnormal sertoli cell (S) (TEM x2500). 


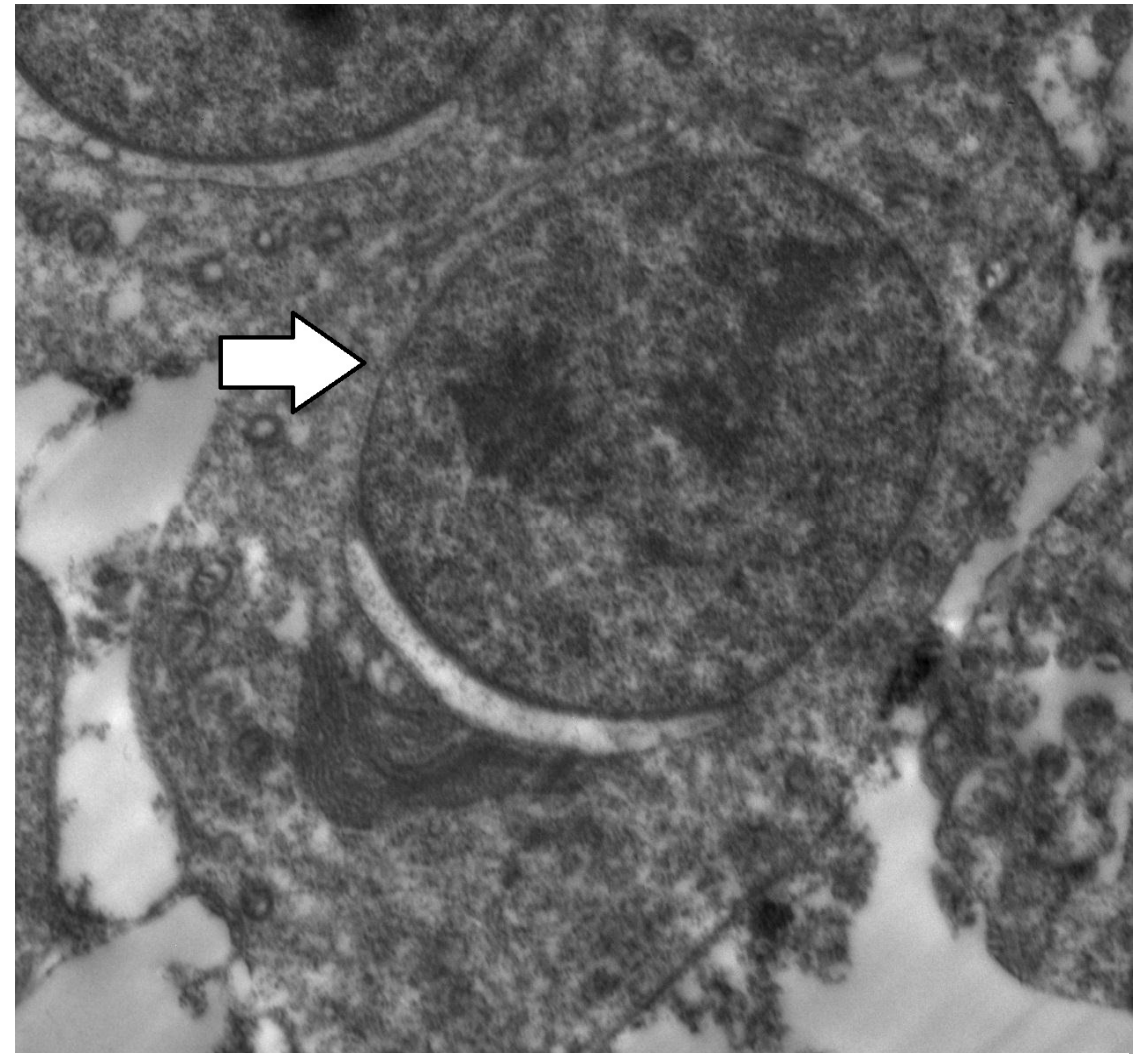

Fig. (5): Electron micrograph of rat's testis prepared from rats in (fluoxetine and vitamin D group) showing improvement in cells of seminiferous tubule with normal interstitial tissues and cells (arrow) (TEM x2500).

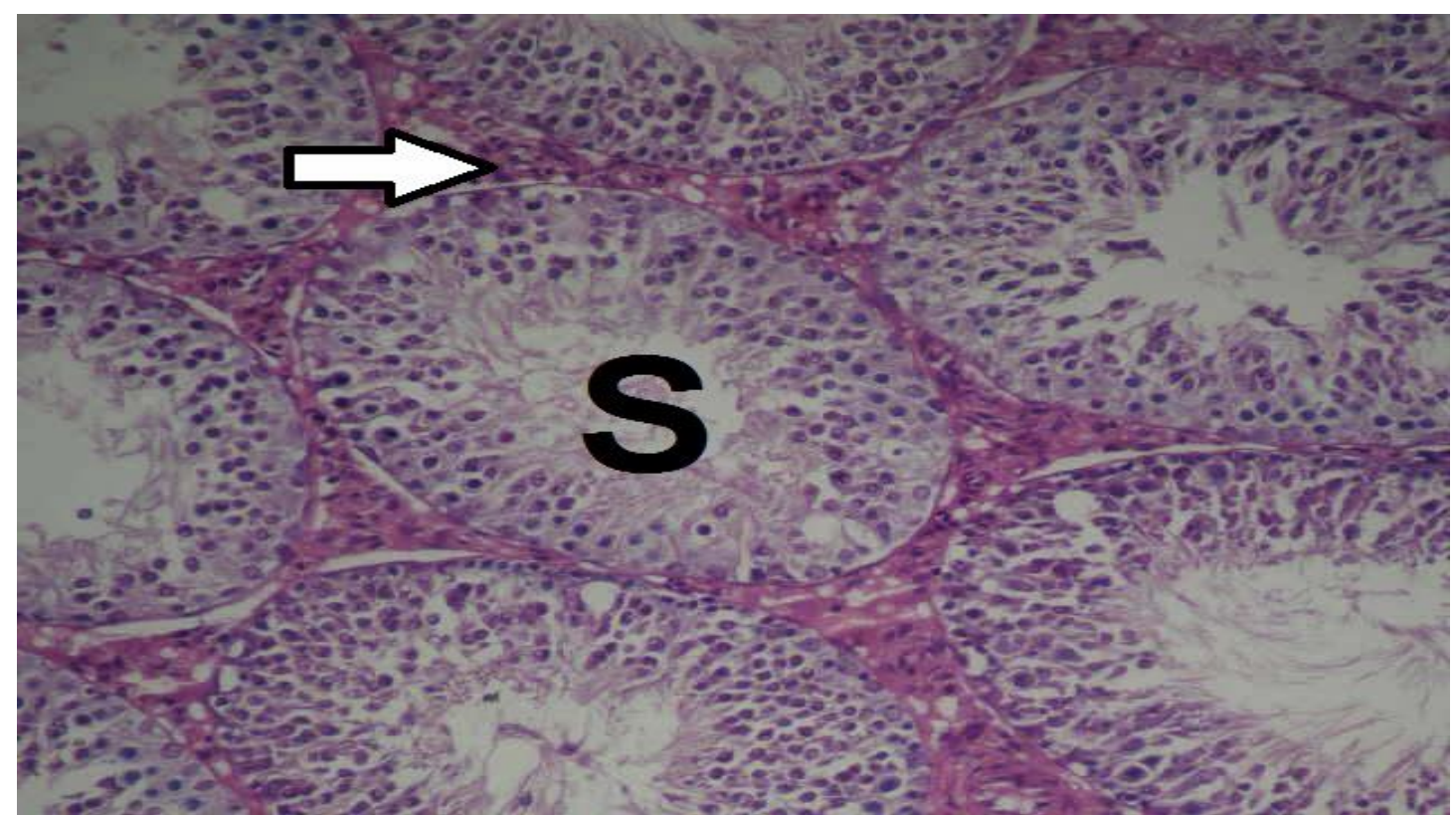

Fig. (6): Photomicrograph of a section in rat's testis prepared from control rat showing normal architecture with well-arranged sertoli cell (S) and normal interstitial tissues (arrow) (Hx \& Ex 200). 


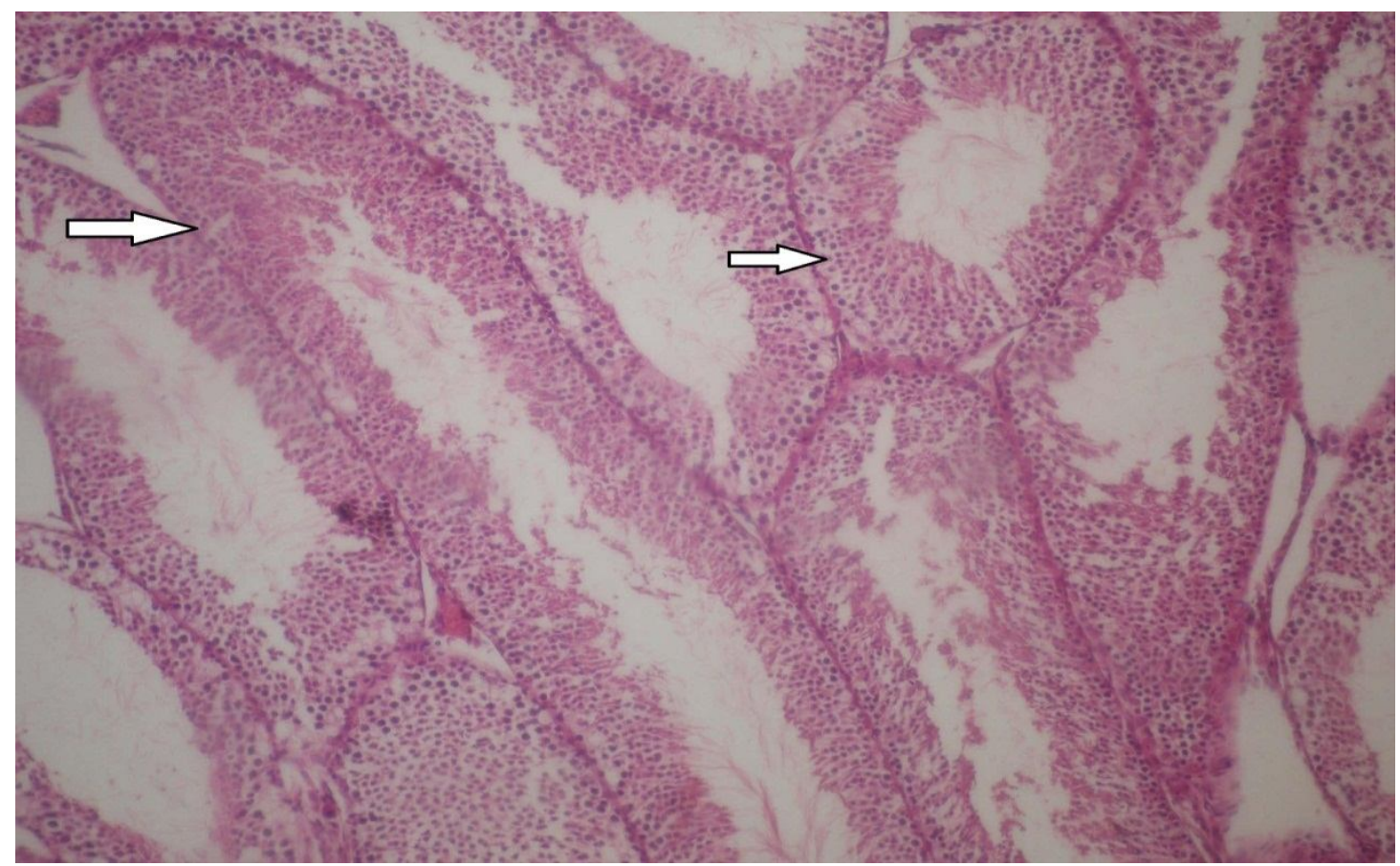

Fig. (7) : photomicrograph of a section in rat's testis prepared from vit D rat grouping showing normal architecture with well-arranged seminiferous tubules (arrow) (Hx \& E $\times 200)$.

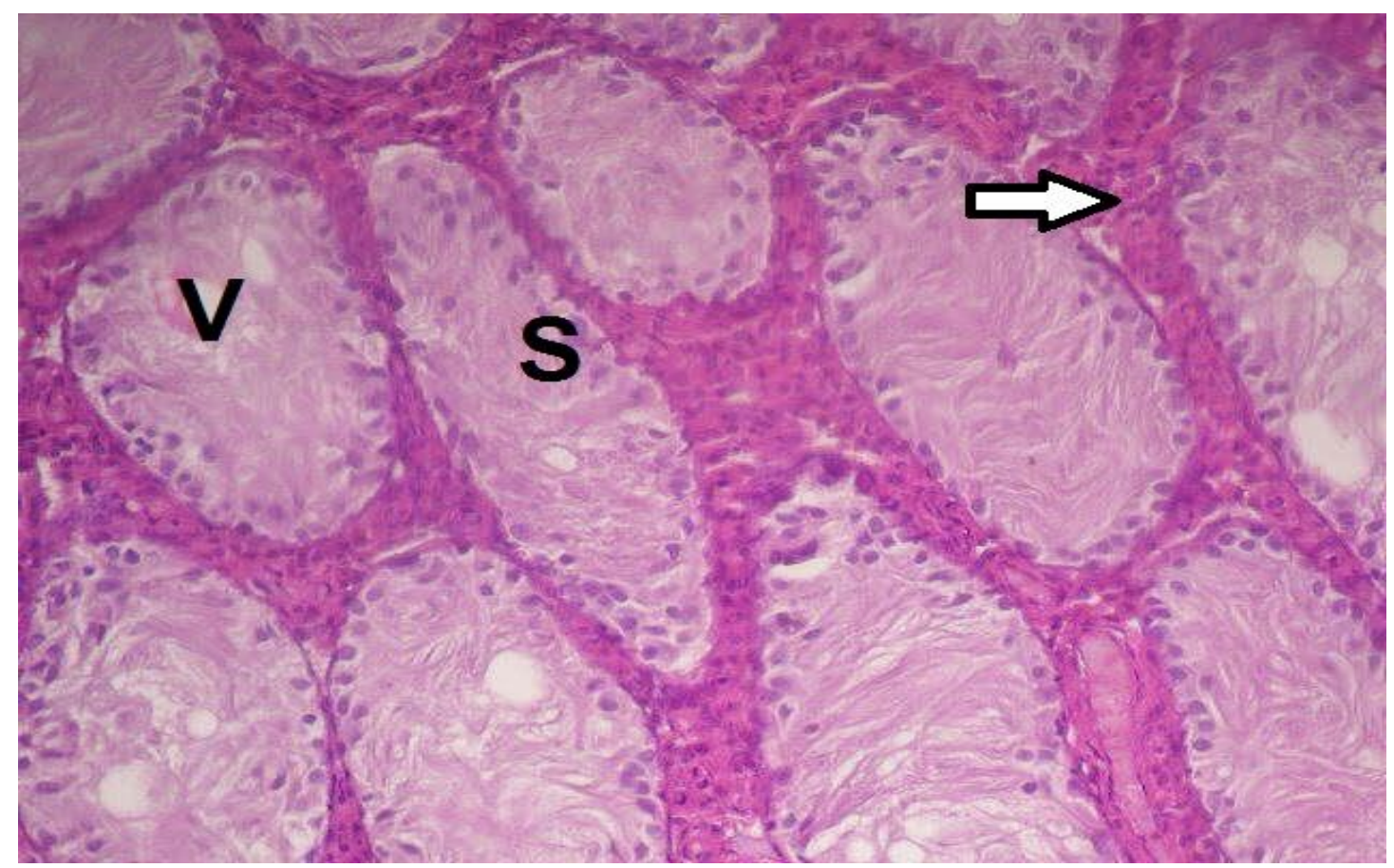

Fig. (8): Photomicrograph of a section in rat's testis prepared from a Fluoxetine treated rat showing testicular atrophy sertoli cell only (S) \& leydig cell hyperplasia ( arrow)And vacuolation (V) (Hx \& E x200). 


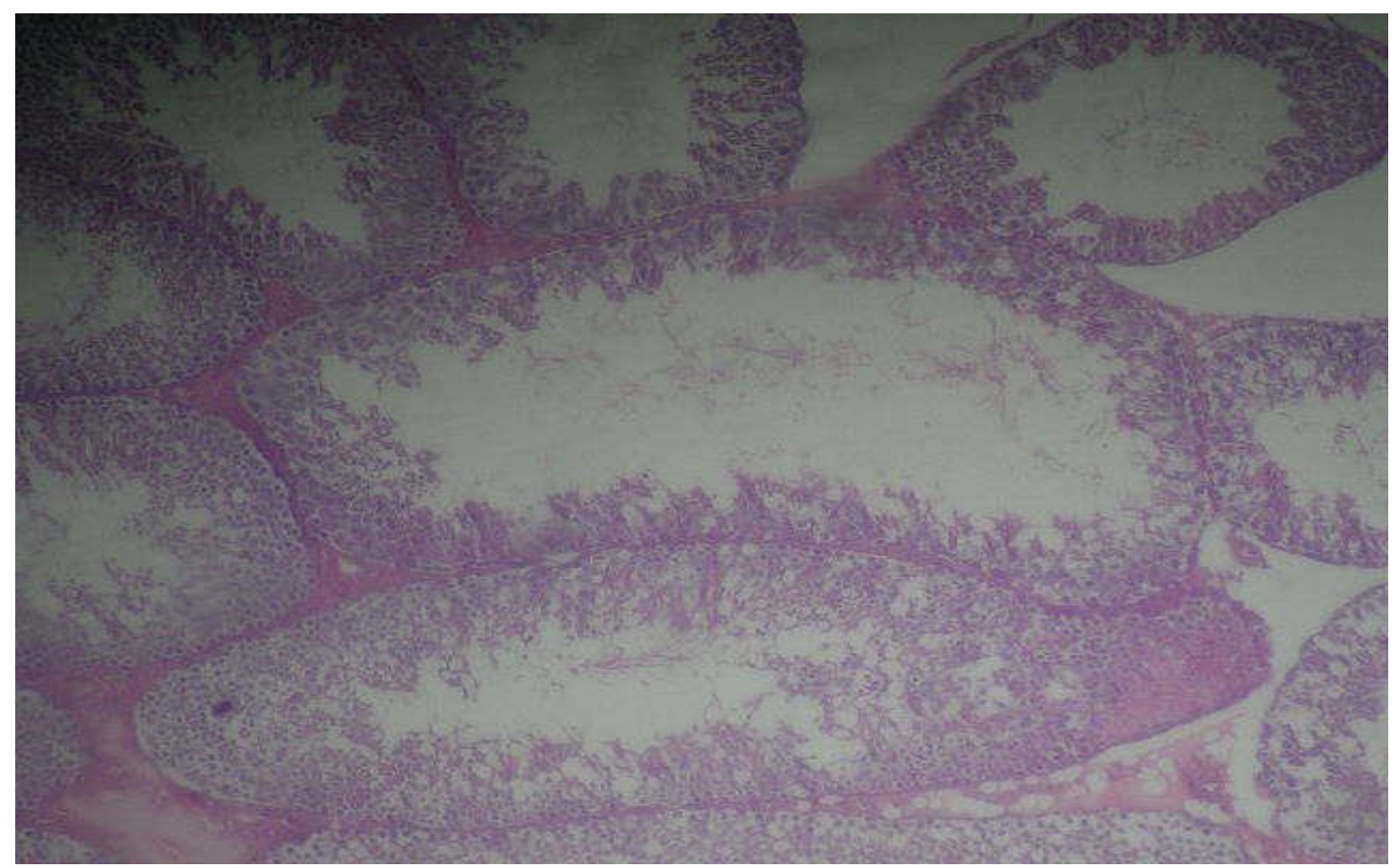

Fig. (9): A photomicrograph of a section in rat's testis prepared from a Fluoxetine and vit D treated rat group showing slightly testicular atrophy (sertoli cell only\& leydig cell hyperplasia) and minimal vacuolation (Hx \& E x200).

\section{Discussion}

About six percent or more of the population experienced a period of depression in their life time (Pilania et al., 2013). Current work has shown that administration of fluoxetine produces a range of adverse effects in the body and on testicular tissues according to Aggarwal et al. (2012) and Sakr et al. (2013).

Simansky (1996) and Morrison et al. (2005), showed that selective serotonin reuptake inhibitors (SSRI's) indirectly inhibit the absorption of food by the intestine and decrease in the nutrients derived through ingestion and intestinal efficient absorption that explains the reduction in body weight in response to fluoxetine. However, it is becoming more and more clear that the size of the testicles largely depends on the amount of germline-derived sertoli cells (Katoh et al., 2002). This study confirms that fluoxetine, an
SSRI, can cause significant testicular atrophy and decreased spermatogenesis.

One notable thing with fluoxetine is that, since it is a well-known and widely prescribed antidepressant drug, it also may have negative side effects, such as reproductive side effects (Bataineh and Daradka, 2007; Silva et al., 2008; Muller et al., 2012).

Many authors explained the mechanism by which fluoxetine induces testicular tissue toxicity. Inkielewicz (2011) showed that fluoxetine induces lipid peroxidation leading to free-radical release, which causes membrane disorganization and subsequent decreases in membrane fluidity, and finally extensive tissue damage.

It was demonstrated by Atli et al. (2017) that selective serotonin reuptake inhibitors (SSRIs), in rats, induce DNA fragmentation and the overproduction of reactive oxygen 
species, which induces cell damage in the male rat's reproductive organs.

Male smokers are much more likely to contract oral-septum, in part due to their high amount of polyunsaturated fats in the plasma membranes, which makes them more vulnerable to oxidative stress (OS) related toxicity (Safarinejad, 2008).

The present findings are consistent with previous studies in that administration of fluoxetine is associated with increases in lipid peroxides in the testes, paralleled by decreased levels of TAC. Furthermore, we also found that fluoxetine can enhance suicidal human reproductive tissues (Mruk and Cheng, 2004).

The current research demonstrated that vitamin $\mathrm{D}$ can provide promising protection against fluoxetine -induced gonadotoxicity. Studies in rats showed that vitamin D can partially alleviate the harmful effects by reversing OS- induced damage in testes thus prevent fluoxetine -induced damage of the rat testes. Thus, vitamin D could be helpful if the therapy is combined with fluoxetine (Nayereh et al., 2013).

Fluoxetine has injurious effects on the testicular tissue including distortion of the seminiferous tubules, degenerated spermatogenic cells with large cytoplasmic vacuoles, and sloughing of germ cells (Hajizadeh et al., 2016).

This study shows that degeneration within a cell (through cell death or apoptosis) could be considered an indication of cell death. This led to the observation of vacuolar lesions in germ cells. This deviation in cell activity would potentially change the morphology of any germ cells in a manner that was consistent with the above results.

The organization of germ cells is thought to be decreased as a result of the effect on the organization of germ cells (by the way it is not human sperm) held by a close relation of the membranes of sertoli cell membranes. The tertiary changes in the affected sertoi cells led them to reduce their secretion of fluid, which along with the apical sloughing and germ cell death led to the situation mentioned earlier (Mruk and Cheng, 2004).

Some germ cell nuclei have deep stains of pyknotic cells. This finding confirms results of Atli et al. (2017) who stated to be gradual degeneration of germ cells.

Within some of the seminiferous tubules, it was found that quite a few, or many, sperm were not there. In other tubules, it was found that there was not much sperm at all. This was in agreement with the study published by Kumar et al. (2006) in which the research study proved that fluoxetine had a spermicidal effect. They claim that they affect sulfhydryl groups in the sperm plasmalemma and that they bind to phospholipids in the sperm to interfere with ATP synthesis in the sperm by binding with the lipid membranes.

The previous studies have shown that the endogenous VD endocrine system regulates the vital functions in each organ. In addition, it has been shown that VD simultaneously promotes several antioxidant enzymes and anti-inflammatory cytokines in a rat model with diabetic nephropathy (Carvalho, 2017; Mohammad et al., 2018). The human testicles have also been observed to be damaged by the same types of pharmaceuticals containing donors of nitric oxide. Thus, it was suggested that VD3 ameliorated fluoxetine-induced testicular tissue injuries in rats only after 21 days of administration.

This study looked at an interaction between a certain compound that is caused by fluoxetine and the blood vessels by measuring Vit D concentrations. Via this study, it can also be determined that Vit D3 
supplementation may help prevent fluoxetine from damaging the testes. Our stock analysis revealed strong evidence that there is a significant increase in the lipid-induced radical formation and that some anti-oxidant enzymes are in a decreased state in the tissues of the brain of people who use electronic cigarettes. Additionally, the fluoxetine treated group had a significantly higher level of proinflammatory cytokines, tumor necrosis factor-alpha (TNF- $\alpha$ ), and interleukin-4 (IL4 ), as well as a lower level of the antiinflammatory cytokine, interleukin- 10 (IL$10)$, in serum and tissues.

Furthermore, the increased production of the ROS may cause apoptotic death of the testicular cells of the fluoxetine administrated rats as evidenced in our study by increased Bax and decreased Bcl-2, which are two members of the Bcl-2 family and play a proapoptotic and antiapoptotic role, respectively. Vitamin D restored these fluxoetine-mediated testicular damages revealing its potential anti-apoptotic property.

Though none of the previous studies measured the effects of fluoxetine toxicity, all of them were unsuccessful. This data showed that vitamin D3 significantly reduced fluoxetine- induced testis damage. Injuries result in an anti-oxidative state, leading to increases in the anti-inflammatory cytokine, IL-10, and a marked decline in the levels of IL-4 and TNF- $\alpha$. Previous research has shown that Vit D causes oxidative stress and IL-10, IL-4, and TNF- $\alpha$ are upregulated in the testis. Therefore, Vit D (with its anti-inflammatory and anti-oxidative properties) could protect against the toxic effects of fluoxetine on testicular cells.

Detailed research is required to establish the role of Vit D3 in preventing the toxicity induced by fluoxetine. Fluoxetine caused significant testicular damage and germ cell apoptosis, which may affect reproduction. Yet combining fluoxetine with vitamin D caused a more superior effect in testicular protection. If a person has depression, it is recommended to take vitamin $\mathrm{D}$ for treatment.

Conclusions: Current study declared that vitamin D supplementation reduced the oxidative stress induced by fluoxetin administration in rats.

Conflict of interest: The authors declare that there is no conflict of interest.

Funding status: There is no financial support.

Acknowledgment: The authors are grateful to the technical and cooperative staff at the departments of Pharmacology, Anatomy, Biochemistry and Clinical Pathology, Faculty of Medicine, Benha University, Egypt for their support during the study.

\section{References:}

Abdelghany, A.H.; BaSalamah, M.A.; Idris, S.; et al. (2016) 'The fibrolytic potentials of vitamin D and thymoquinone remedial therapies: insights from liver fibrosis established by CCl4 in rat', J. Transl. Med.; 14, p. 281.

Aggarwal, A.; Jethani, S.L.; Rohatgi, R.K.; et al. (2012) 'Effects of fluoxetine on testis of albino rats-a histological assessment', Int. J. Sci. Eng. Res.; 3(7), p.1-5.

Atli, O.; Baysal, M.; Aydogan-Kilic, G.; et al. (2017) 'Sertraline - induced reproductive toxicity in male rats: evaluation of possible underlying mechanisms', Asian. J. Androl. 19, p.1-8.

Bataineh, H.N. and Daradka, T. (2007) 'Effects of long-term use of fluoxetine on fertility parameters in adult male 
rats', Neuro. Endocrinol Lett.; 28(3), p.321-325.

Carlberg, C. and Campbell, M.J. (2013) 'Vitamin D receptor signaling mechanisms: integrated actions of a well-defined transcription factor', Steroids; 78, p.127-136.

Chow, E.C.; Quach, H.P.; Vieth, R.; et al. (2013) 'Temporal changes in tissue 1alpha,25-dihydroxyvitamin D3, vitamin $\mathrm{D}$ receptor target genes, and calcium and PTH levels after $1,25(\mathrm{OH}) 2 \mathrm{D} 3$ treatment in mice', Am. J. Physiol. Endocrinol. Metab.; 304, p. 977-989.

Carvalho, J.; Marion T.G.; Lilian C.; et al. (2017) 'Cholecalciferol decreases inflammation and improves vitamin D regulatory enzymes in lymphocytes in the uremic environment: A randomized controlled pilot trial', PLoS One. https://doi.org/10.1371/journal.pone.

Dowlati, Y.; Herrmann, N.; Swardfager, W.; et al. (2010) 'A meta-analysis of cytokines in major depression', Biol. Psychiatry; 67, p.446-457.

Hajizadeh, Z.; Mehranjani, M.; Najafi, G.; et al. (2016) 'Black grape seed extract modulates fluoxetine-induced oxidative stress and cytotoxicity in the mouse testis', J. Nat. Pharm. Prod., 11(2), p.26. Howren, M.B.; Lamkin, D.M. and Suls, J. (2009) 'Associations of depression with C-reactive protein, IL-1, and IL-6: a meta-effect of fluoxetine and resveratrol on testicular functions and oxidative stress in a rat model of chronic mild stress-induced depression analysis', Psychosom. Med.; 71, p.171186.

Hussein, F.; Amr, A.; Ayman, Z.; et al. (2015) 'Effect of fluoxetine and resveratrol on testicular functions and oxidative stress in a rat model of chronic mild stress-induced depression', J. Physiol. Pharmacol., 66(4), p.515527.

Inkielewicz, S.I. (2011) 'Impact of fluoxetine on liver damage in rats', Pharmacol. Rep. J.; 63, p.441-447.

Jalili, T.; Khaki, A.; Ghanbari, Z.; et al. (2014) 'A Study of the therapeutic effects of vitamin e on testicular tissue damage caused by fluoxetine use', Crescent. J. Med. and Biol. Sci.; 1, p.3741.

Johnsen, S.G. (1970) 'Testicular biopsy score count-a method for registration of spermatogenesis in human testes: normal values and results of 335 hypogonadal males', Hormones; 1, p. 225.

Katoh, C.; Kitajima, S.; Saga, Y.; et al. (2002) 'Assessment of quantitative dualparameter flow cytometric analysis for the evaluation of testicular toxicity using cyclophosphamide- and ethinylestradiol-treated rats', J. Toxicol. Sci.; 27(2), p.87-96.

Kiernan, J.A. (2015) 'Histological and histochemical methods; theory and practice', 5th Ed Oxford, UK: Butterworth Heinemann; p. 238-310.

Kumar, V.S.; Sharma, V.L.; Tiwari, P.; et al. (2006) 'The spermicidal and antitrichomonas activities of SSRI antidepressants', Bioorg. .Med. Chem. Lett. J.; 16, p. 2509-2512.

Lopez, F.; Schepelmann, M.; Brennan, SC.; et al. (2015) 'The calcium-sensing receptor: one of a kind', Exp. Physiol.; 100, p.1392-1399.

Morrison, J.L.; Riggs, K.W. and Rurak, D.W. (2014) 'Fluoxetine during pregnancy: impact on fetal development', Reprod. Fertil. Dev.; 17(6), p.641-650. 
Mohammad, A.; Abdelghany. B.; Abdelghany. H.; et al. (2018) 'Vitamin $\mathrm{D}$ alleviates lead induced renal and testicular injuries by immunomodulatory and antioxidant mechanisms in rats', 8,p.4853. DOI:10.1038/s41598018-23258.

Mruk, D.D and Cheng, C.Y. (2004) 'SertoliSertoli and Sertoli-germ cell interactions and their significance in germ cell movement in the seminiferous epithelium during spermatogenesis', Endocr. Rev.; 25(5), p.747-806.

Muller, J.C.; Imazaki, P.H.; Boareto, A.C.; et al. (2012) 'In vivo and in vitro estrogenic activity of the antidepressant fluoxetine', Reprod. Toxicol.; 34(1), p.80-85.

Pilania, M.; Bairwa, M.; Kumar, N.; et al. (2013) 'Elderly depression in India: An emerging public health challenge', Australas Med. J.; 6(3), p.107-111.

Refaat, B.; Ahmad, J.; Idris, S.; et al. (2017) 'Characterisation of vitamin Drelated molecules and calcium-sensing receptor in human Fallopian tube during the menstrual cycle and in ectopic pregnancy', Cell Tissue Res.; 368, p. 201-213.

Refaat, B.; El-Shemi, A.G.; Ashshi, A.; et al. (2015) 'Vitamin D and chronic hepatitis C: effects on success rate and prevention of side effects associated with pegylated interferon-alpha and ribavirin', Int. J. Clin. Exp. Med.; 8, p. 303.

Rogerio, F.; Jordao, H.; Vieira, A.S.; et al. (2006) 'Bax and Bcl-2 expression and TUNEL labeling in lumbar enlargement of neonatal rats after sciatic axotomy and melatonin treatment', Brain Res.; 80 , p. 90.
Sakr, S.A.; Mahran, H.A. and El-Deeb, M.M (2013) 'Ameliorative effect of curcumin on fluoxetine-induced reproductive toxicity and oxidative stress in male albino rats', Oxid. Antioxid. Med. Sci.; 2(1), p. 29-35.

Schmittgen, T. and Livak, K. (2008) 'Analyzing real-time PCR data by the comparative C (T) method', Nat. Protoc., 3, p. 1101- 1108.

Silva, J.; Lins, A.; Amorim, J.; et al. (2008) 'Neonatal administration of fluoxetine decreased final sertoli cell number in Wistar rats', Int. J. Morphol., 26(1), p.51-62.

Safarinejad, M.R. (2008) 'Evaluation of endocrine profile and hypo-thalamicpituitary-testis axis in selective serotonin reuptake inhibitor-induced male sexual dysfunction', J. Clin. Psychopharmacol.; 28(4), p.418-423.

Simansky, K.J. (1996) 'Serotonergic control of the organization of feeding and satiety', Behav. Brain Res.; 73(1-2), p.37-42.

Nayereh, K.; Mehdi, T.D, Shima, J.; et al. (2013) 'Therapeutic effects of vitamin D as adjunctive therapy to fluoxetine in patients with major depressive disorder', Aust. N. Z. J. Psychiatry.; 47(3), p.271275.

Wille, S.M.R.; Cooreman, S.G. and Neels, H.M. (2008) 'Relevant issues in the monitoring and the toxicology of antidepressants', Crit. Rev. Clin. Lab. Sci.; 45, p.25-89.

Wong, H.; Anderson, W.D.; Cheng, T.; et al. (1994) 'Monitoring mRNA expression by polymerase chain reaction: the 'primer-dropping' method', Anal. Biochem.; 223, p.251-258. 


\title{
تأثير فيتامين (د) على تسمم الخصية المستحث بالفلوكستين في ذكور الجرذان البالغة
}

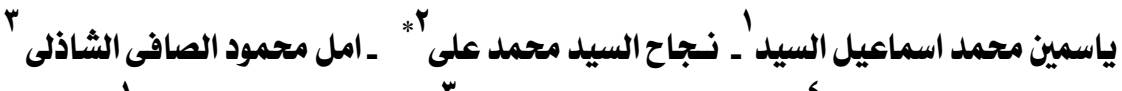

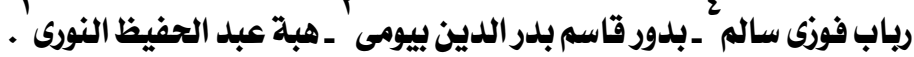

\author{
1 - قسم الفارماكولوجى- جامعة بنها

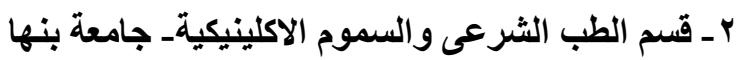 \\ r- قسم التشريح- جامعة بنها \\ ـ ـ قسم الكيمياء الحيويةـ جامعة بنها
}

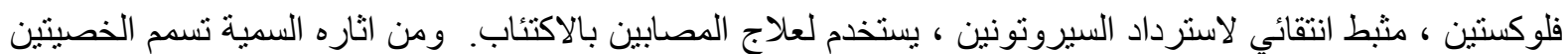

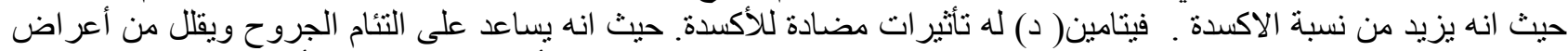

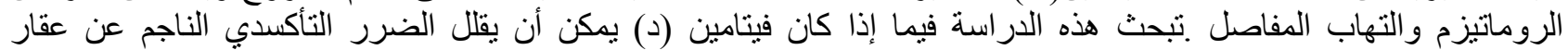

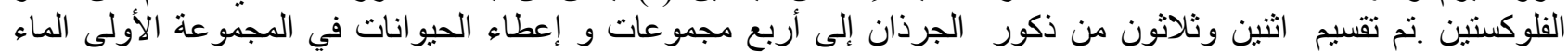

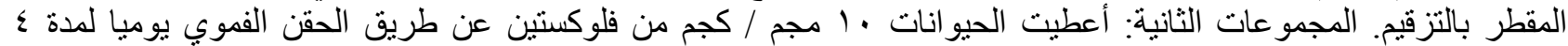

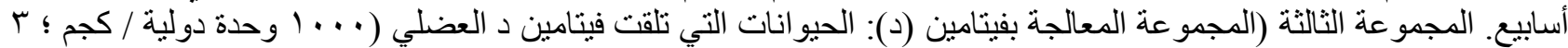

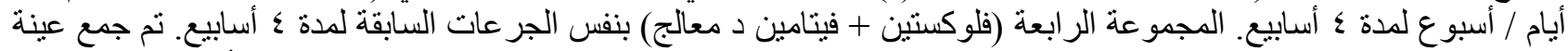

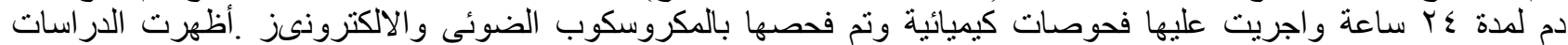

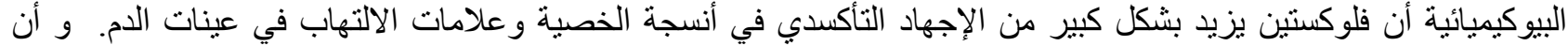

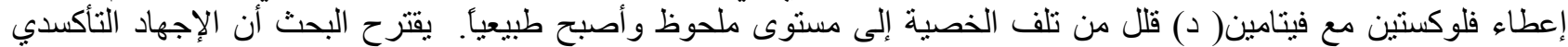

الناجم عن إعطاء فلوكستين في الفئر ان يمكن تقليله عن طريق مكملات فيتامين (د). 